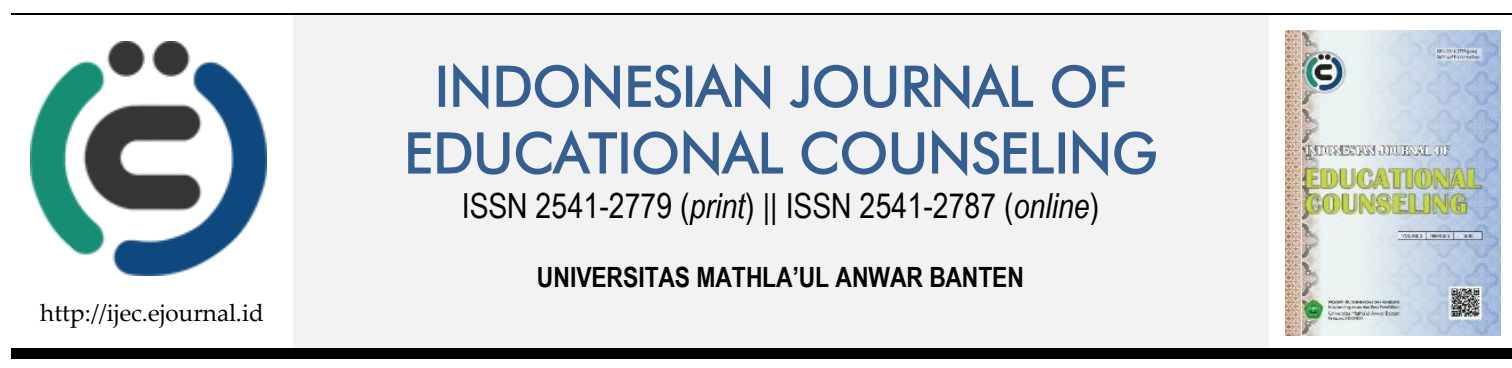

Research Based Article

\title{
Identifikasi Kecenderungan Bakat dan Pengaruhnya Terhadap Hasil Belajar Mahasiswa Bimbingan dan Konseling
}

\author{
Mudaim ${ }^{1}$, Agus Wibowo ${ }^{2}$ \\ 1,2 Universitas Muhammadiyah Metro
}

\begin{tabular}{ll}
\hline ARTICLE INFO & ABSTRACT \\
\cline { 2 - 3 } $\begin{array}{l}\text { Article History: } \\
\text { Received 29.10.2017 }\end{array}$ & $\begin{array}{l}\text { The success of the learning process undertaken by individuals is not only } \\
\text { Received in revised } \\
\text { form 06.02.2018 }\end{array}$ \\
identification of the influence of mental state is something very important. The \\
Accepted 05.07.2018 \\
Available online
\end{tabular}$\quad \begin{aligned} & \text { potential aspect thatent. The purpose of this research is to identify student talent so that } \\
& \text { lecturers can do the learning process by taking into account individual } \\
& \text { differences, potentials and talents. This research was conducted at } \\
& \text { Muhammadiyah University of Metro. The population is all students of } \\
& \text { Guidance and Counseling University of Muhammadiyah Metro and the sample } \\
& \text { is determined by stratified random sampling. The research instrument uses } \\
& \text { talent test and student learning outcomes in the form of KHS. Analysis of } \\
& \text { correlational data using product moment. The results showed scholastic talent } \\
& \text { and student learning outcomes Guidance and Counseling University } \\
& \text { Muhammadiyah Metro is in the medium category. The contribution of } \\
& \text { scholastic talent to learning result or achievement index is 55,5\%. and the } \\
& \text { correlation is } 0.747 \text { with sig.0.00. }\end{aligned}$

Keywords: Learning Outcomes, Talent.

\section{PENDAHULUAN}

Proses belajar sebagai aktifitas mental tingkat keberhasilannya dipengaruhi oleh banyak faktor. Namun kondisi yang ditunjukkan dalam pelaksanaan proses pendidikan di Indonesia sering kali mengabaikan proses mental tersebut. Bahkan perbedaan individual dalam proses belajar kerap diabaikan. Belum lagi adanya anggapan bahwafaktor inteligensi masih menjadi patokan atau dasar yang diprediksi menjadi penentu keberhasilan akademik. Hasil temuan Pali (2011) menjelaskan bahwa faktor

${ }^{1}$ Corresponding author's address: Program Studi Bimbingan dan Konseling, FKIP Universitas Muhammadiyah Metro; Jalan K.H Dewantara No. 116, Metro Pusat, Iringmulyo, Metro Timur, Kota Metro, Lampung, Indonesia 34125. Email: mudaim79@gmail.com. 
potensi bawaan atau bakat menjadi salah satu faktor yang juga memiliki kontribusi terhadap keberhasilan akademik peserta didik selain faktor-faktor lain. Oleh karena pengembangan potensi (bakat) individu menjadi suatu hal yang sangat penting ketika pendidik menginginkan proses belajar dan pembelajaran yang diselenggarakannya memperoleh hasil yang optimal.

Sebagai faktor yang memiliki peran besar dalam menunjang proses dan hasil belajar,maka pemahaman dan pengembangan bakat individu menjadi hal penting yang harus diperhatikan. Bakat adalah potensi yang dimiliki oleh individu yang dapat berkembang dan dapat menjadikan individu mencapai kesuksesan. Wasty (1998) mengutip hasil penelitian dari Stemberg, menyebutkan bahwa kemampuan manusia itu bukanlah sebuah kemampuan yang sifatnya sudah baku pada satu bentuk atau titik tertentu (not fixed ability), tetapi sebuah kemampuan yang sifatnya terus berkembang (developing abilities). Potensi yang memiliki sifat berkembang, disaat memndapatkan kondisi dan dukungan yang baik akan menjadikan individu semakin mampu untuk mencapai kesuksesan belajarnya.

Individu yang tidak berbakat akan sukar untuk mempelajari sesuatu secara mendalam. Menurut Hilgard (1968), bakat adalah kemampuan untuk belajar. Pendapat tersebut menjelaskan bahwa perilaku belajar sangat berkaitan dengan potensi yang dimiliki oleh individu. Suryabrata (1993) menjelaskan bahwa anak berbakat merupakan suatu interaksi antara tiga sifat dasar manusia yang menyatu dalam satu ikatan yang terdiri dari kemampuan umum dan dengan tingkatnya diatas kemampuan rata-rata, komitmen yang tinggi terhadap tugas-tugas, dan kreativitas yang tinggi.

Individu yang melakukan aktiffitas belajar cenderung sesuai dengan potensi atau bakat yang dimiliki berkesempatan untuk memperoleh hasil belajar yang lebih baik. Dukungan dari bakat dapat terlihat dari rasa keinginan untuk mencapai tujuan belajar yang dilakukan, motivasi yang tinggi dalam belajar, dan kenyamanan dan mempelajari dan menguasai sesuatu yang sesuai dengan potensinya. Sebagai proses perubahan melalui latihan dan juga telaah pengalaman yang didukung dari pengembangan potensi diri, perilaku belajar akan lebih efektif. Belajar pada dasarnya adalah upaya untuk menguasai sesuatu yang baru dengan memanfaatkan apa yang sudah ada pada diri individu. Pernyataan di atas diperkuat oleh pendapat Howard L. Kingsley (1946) menjelaskan bahwa "Learning is the process by which behavior (in the broader sense) is originated or changed through practice or training". Belajar adalah suatu proses di mana tingkah laku dalam arti luas ditimbulkan atau diubah melalui pelatihan atau pengalaman

Dari definisi belajar di atas dapat dipahami bahwa belajar adalah suatu proses yang akan menghasilkan perubahan tingkah laku kepada arah yang positif sebagai hasil belajar. Dalam proses belajar tentunya akan ditemui kesulitan atau masalah. Masalah belajar tersebut merupakan suatu keadaan dimana siswa tidak dapat belajar sebagaimana mestinya (Ahmadi \& Supriono, 2003). Keadaan tersebut terjadi karena: 1) Tidak mengetahui bagaimana cara belajar yang baik; 2) Tidak mengetahui bagaimana cara membaca buku dengan baik agar dapat memahami isinya; 3) Tidak mengetahui bagaimana cara mempersiapkan diri untuk menghadapi ujian.

Proses belajar akan efektif apabila orientasinya adalah pada siswa itu sendiri. Hal tersebut sesuai dengan pernyataan Ananda (2010) adalah belajar yang berpusat pada siswa, karena itu guru harus memiliki tujuan yang jelas dan persiapan yang matang sebelum proses belajar dimulai. Belajar menghendaki adanya proses pelibatan diri sendiri dan membangun struktur konseptual melalui refleksi dan abstraksi. 
Saat ini proses pembelajaran pada program studi Bimbingan dan Konseling (BK) Universitas Muhammadiah Metro masih sangat minim memperhatikan bakat sebagai potensi yang dapat mempengaruhi proses belajar. Hal ini berakibat hasil belajar mahasiswa belum optimal. Sebagian mahasiswa dapat dikatakan tertinggal dalam hal hasil belajar. Faktor penting yang diduga mempengaruhi hasil belajar mahasiswa adalah pemahaman mengenai bakat siswa, terutama bakat skolastik. Sehingga siswa yang memiliki bakat berbeda diperlakukan sama dalam proses pembelajaran. Tentu hal ini menjadi suatu masalah pembelajaran.

Berangkat dari kondisi tersebut, peneliti tertarik untuk melakukan penelitian yang mencari apakah faktor bakat skolastik mempengaruhi kondisi belajar dan prestasi belajar mahasiswa. Munandir (1991) mengatakan, bahwa bakat sering dikatakan merupakan kemampuan yang dibawa sejak lahir, dengan kata lain bersifat keturunan. Melalui penelitian ini diharapkan dapat menjadi pijakan dalam mengidentifikasi dan membantu mahasiswa menemukan proses dan gaya belajar yang sesuai dengan bakatnya.

\section{METODE}

Penelitian ini menggunakan pendekatan ex-post facto. Penelitian jenis ex-post facto yang dimaksud merupakan keterkaitan antar variabel bebas dengan variabel bebas, maupun antar variabel bebas dengan variabel terikat sudah terjadi secara alami. Peneliti dengan setting tersebut ingin melacak kembali jika dimungkinkan apa yang menjadi faktor penyebabnya. Jenis pelitiannya adalah penelitian deskriftif korelasional. Penelitian ini akan mengklasifikasikan bakat dan hasil belajar mahasiswa BK Universitas Muhammadiyah Metro, Kota Metro, Lampung selanjutnya akan menguji keterkaitan antar variabel tersebut.

Bakat merupakan segenap potensi yang dimiliki oleh individu yang sifatnya dapat dikembangkan dan sangat erat kaitanya dengan faktor ekternal. Dalam penelitian ini yang akan diungkapkan adalah bakat skolastik (numerikal dan verbal). Sedangkan hasil belajar adalah tingkat capaian individu setelah melakukan proses belajar. Hasil belajar tercakup dalam komponen bidang keilmuan dan pengetahuan (kognitif), bidang personal (afektif) serta bidang kelakuan (psikomotorik). Dalam penelitian ini hasil belajar dilihat dari indeks prestasi (IP) mahasiswa.

Populasi penelitian yaitu seluruh mahasiswa aktif Bimbingan dan Konseling angkatan. Sampel penelitian ditentukan dengan teknik stratifedrandom sampling. Sampel penelitian adalah seluruh mahasiswa semester IV yang berjumlah 64 mahasiswa. Untuk mengumpulkan data penelitian, maka instrumen yang digunakan adalah tes bakat dan dokumentasi untuk mengumpulkan data hasil belajar mahasiswa

Teknik analisis data dijabarkan menjadi tiga, yaitu analisis deskriptif, uji prasyarat analisis data dan uji hipotesis. Analisis deskriptif digunakan untuk menganalisis data secara umum dengan teknik statistik. Analisis deskriptif bertujuan untuk mengelompokkan data sesuai dengan kategori yang ditentukan pada masing-masing variabel. Analisis deskriptif digunakan untuk menentukan presentase disetiap variabel sesuai dengan kategorinya. Uji prasyarat analisis data terdiri atas uji normalitas. Uji normalitas digunakan untuk mengetahui sampel data dari populasi berdistribusi normal. Uji hipotesis menggunakan uji korelasi product moment. 


\section{HASIL DAN PEMBAHASAN}

\section{Deskripsi Kecenderungan Bakat Skolastik Mahasiswa BK}

Untuk mengetahui bakat skolastik pada mahasiswa Bimbingan dan Konseling Universitas Muhammadiyah Metro, maka sampel penelitian dilakukan tes bakat yang dilaksanakan bekerjasama dengan laboratorium Bimbingan danKonseling. Berdasarkan analisis data tes bakat yang dilakukan, mahasiswa yang memiliki bakat skolastik rendah 28 mahasiswa (33,75\%), bakat skolastik sedang sebanyak 32 mahasiswa (50\%), dan 4 mahasiswa (6.25\%) lainnya memiliki bakat skolastik yang tinggi. Demikian secara umum dapat disimpulkan bahwa bakat skolastik mahasiswa Bimbingan dan Konseling Universitas Muhammadiyah Metro semester IV tahun akademik 2016/2017 berada pada kategori rendah.Secara rinci hasil tes bakat skolastik disajikan pada Tabel 1.

Tabel 1. Distribusi Bakat Skolastik Mahasiswa Bimbingan dan Konseling Semester IV Tahun Ajaran 2016/2017

\begin{tabular}{lccc}
\hline \multicolumn{1}{c}{ Kategori Bakat Skolastik } & Interval Skor & Frekuensi & $\%$ \\
\hline Tinggi & $>74$ & 4 & 6,25 \\
\hline Sedang & $49-74$ & 32 & 50 \\
\hline Rendah & $<49$ & 28 & 43,75 \\
\hline Jumlah & & 64 & 100 \\
\hline
\end{tabular}

Berdasarkan Tabel 1, dapat diketahui bahwa secara rata-rata mahasiswa program studi Bimbingan Dan Konseling Universitas Muhammadiyah Metro memiliki kecenderungan bakat skolastik yang sedang, yaitu 50\%. Kondisi ini menggambarkan bahwa potensi akademik (skolastik) cukup baik. Kondisi potensi akademik atau skolastik yang digambarkan pada hasil riset ini menjadi pijakan bahwa sebagian besar mahasiswa Program Studi Bimbingan dan Konseling memiliki kemampuan yang cukup baik dalam melaksanakan proses pembelajaran.

Hasil penelitian juga menggambarkan, bahwa pada 43,75\% mahasiswa Program Studi Bimbingan dan Konseling memiliki potensi akademik yang masih rendah. Hal ini menjadi menarik bahwa, tingkat potensi skolastik yang rendah masih cukup besar dan hal ini akan sangat mempengaruhi indeks ketercapaian proses pembelajaran pada mahasiswa bimbingan dan konseling secara umum, apalagi dukungan dari mahasiswa yang memiliki potensi skolastik tinggi tidak signiikan, yaitu sebesar 6,25\%.

\section{Deskripsi Hasil Belajar Mahasiswa BK}

Untuk mengetahui hasil belajar yang diperoleh pada indek prestasi mahasiswa, maka dilakukan penelusuran dokumen mahasiswa di Biro Administrasi dan Akademik Kemahasiswaan (BAAK) Universitas Muhammadiyah Metro. Hasilnya disajikan pada Tabel 2.

Tabel 2. Distribusi Hasil Belajar Mahasiswa Bimbingan dan Konseling Semester IV Tahun Ajaran 2016/2017

\begin{tabular}{cccc}
\hline Kategori & Interval & Frekuensi & $\%$ \\
\hline Tinggi & $>3,45$ & 9 & 14,063 \\
\hline Sedang & $3,14-3,45$ & 44 & 68,75 \\
\hline Rendah & $<3,14$ & 11 & 17,188 \\
\hline & Jumlah & 64 & 100 \\
\hline
\end{tabular}


Berdasarkan analisis terhadap data hasil belajar yang dikumpulkan, maka dapat dideskripsikan bahwa mahasiswa yang memiliki hasil belajar rendah sebanyak 11 mahasiswa (17,188\%), hasil belajar sedang sebesar 44 mahasiswa $(68,75 \%)$, dan yang memiliki hasil belajar tinggi sebesar 9 mahasiswa (14,063\%).

Kondisi yang digambarkan pada Tabel 2 menunjukkan bahwa, secara umum indek prestasi (IP) mahasiswa berada pada tingkat yang sedang. Angka $68,75 \%$ pada kategori sedang, menjelaskan bahwa efektifitas proses pembelajaran yang dilakukan oleh mahasiswa program studi Bimbingan dan Konseling Universitas Muhammadiyah Metro belum terlalu memuaskan atau belum maksimal. Bahkan, jika diperhatikan pada kategori hasil belajar yang tinggi hanya $14,063 \%$, menunjukkan tingkat efektifitas yang rendah. Oleh karena itu dapat disimpulkan bahwa secara umum hasil belajar mahasiswa Bimbingan dan Konseling Universitas Muhammadiyah Metro semester IV Tahun Ajaran 2016/2017 berada pada kategori hasil belajar sedang.

Setelah menggambarkan kondisi kedua variabel, bakat skolastik dan hasil belajar selanjutnya akan diuji apakah kedua variabel tersebut memiliki keterkaitan atau hubungan. Langkah yang dilakukan dalam pengujian keterkaitan tersebut dilakukan dalam beberapa langkah, yaitu:

\section{Uji Normalitas}

Berdasarkan perhitungan, diketahui bahwa nilai Sig. Skor bakat skolastik 0,024, lebih rendah dari 0,05, dengan demikian disimpulkan bahwa data penelitian variabel bakat skolastik berdistribusi normal. Selanjutnya, diketahui bahwa nilai Sig. data hasil belajar mahassiwa bimbingan dan konseling sebesar 0,042, lebih kecil dari 0,05, dan dapat diartikan bahwa penyebaran data hasil belajar berdistribusi normal Setelah diketahui bahwa distribusi data kedua variabel berdistribusi normal, maka tahap selanjutnya adalah melakukan pengujian terhadap hipotesis penelitian

\section{Pengujian Hipotesis}

Perhitungan uji hipotesis dilakukan untuk mengetahui kontribusi bakat skolastik terhadap hasil belajar mahasiswa. Berdasarkan perhitungan pada Tabel 3, diketahui bahwa terdapat hubungan antara bakat skolastik dengan hasil belajar, dengan $r$ hitung sebesar 0,747 dan sig .0,00, yang berarti terdapat hubungan yang sangat erat. Hasil perhitungan tersebut menjelaskan bahwa antara variabel bakat skolastik memiliki kaitan dengan variabel hasil belajar. Dengan demikian dapat dijelaskan bahwa salah satu faktor untuk meningkatkan hasil belajar mahasiswa program studi Bimbingan dan Konseling adalah melalui upaya peningkatan kualitas potensi atau bakat skolastik mahasiswa. Hal tersebut dapat dilakukan dikarenakan pada hakikatnya bakat adalah suatu potensi yang dapat untuk dikembangkan.

Tabel 3. Uji hipotesis

\begin{tabular}{lll}
\hline & & Hasil_belajar \\
\hline Bakat_skolatik & Pearson Correlation & $.747^{\star *}$ \\
& Sig. (2-tailed) & .000 \\
& $\mathrm{~N}$ & 64 \\
\hline
\end{tabular}

Selanjutnya untuk mengetahui kontribusi variabel bakat skolastik terhadap hasil belajar, maka analisis akan dilanjutkan dengan perhitungan berikut: 


$$
\begin{aligned}
\mathrm{KD} & =\mathrm{r} 2 \times 100 \% \\
& =0,558 \times 100 \% \\
\mathrm{KD} & =55,8 \%
\end{aligned}
$$

Merujuk kepada hasil perhitungan di atas, diketahui bahwa koefisien determinasi (KD) variabel bakat skolastik terhadap hasil belajar mahasiswa sebesar 55,8\%. Artinya bahwa variabel bakat memiliki pengaruh yang cukup besar terhadap perolehan hasil belajar mahasiswa. Berdasarkan hasil perhitungan dan analisa terhadap pengujian hipotesis yang telah dilakukan maka, hipotesis yang menyatakan bakat skolastik berkontribusi terhadap hasil belajar diterima, bakat skolastik berpengaruh terhadap hasil belajar mahasiswa program studi Bimbingan dan Konseling Universitas Muhammadiyah Metro.

\section{SIMPULAN}

Secara umum bakat skolastik mahasiswa Bimbingan dan Konseling Universitas Muhammadiyah Metro Semester IV tahun akademik 2016/2017 berada pada kategori rendah. Hasil belajar mahasiswa Bimbingan dan Konseling Universitas Muhammadiyah Metro Semester IV tahun akademik 2016/2017 berada pada kategori sedang.

Bakat skolatik berkontribusi cukup signifikan, yaitu 55,8\%, dan korelasi cukup signifikan dengan $r$ hitung sebesar 0,747 dan sig.0,00, yang berarti terdapat hubungan yang sangat erat antara bakat skolastik dengan hasil belajar mahasiswa Bimbingan dan Konseling Universitas Muhammadiyah Metro. Berdasarkan korelasi yang cukup signifikan, maka untuk meningkatkan hasil belajar mahasiswa, hendaknya dosen mempertimbangkan bakat skolastik mahasiswa dalam memberikan dan memilih metode pembelajaran. Kecenderungan bakat yang telah diketahui dapat dijadikan pijakan dalam menentukan pekerjaan yang sesuai dengan bakat yang dimiliki.

\section{REFERENSI}

Ahmadi, A., \& Supriyono, W. (2003). Psikologi belajar. Jakarta: Rineka Cipta.

Ananda, A. (2010). Modul strategi pembelajaran. Padang: FIS UNP.

Hilgard, E. R. (1968). Creativity: Slogan and substance. Centennial Review, 12(1), 40-58.

Kingsley, H. L. (1946). The nature and conditions of learning. Oxford, England: Prentice-Hall.

Munandir et al. (1991). Validasi dan penormaan tes kemampuan mental umum ("Inteligensi") dan tes bakat diferensial. (Unpublished research report) IKIP Malang, Malang, Indonesia.

Pali, M. (2011). Kecerdasan dan bakat sebagai prediktor prestasi belajar siswa dan kinerja profesi. Pidato Pengukuhan Guru Besar FIP Universitas Negeri Malang.

Suryabrata, S. (1993). Psikologi pendidikan. Cet. 6. Jakarta: Raja Grafindo Persada.

Wasty, S. (1998). Psikologi pendidikan. Jakarta: Rineka Cipta. 